\title{
QUALITY SERVICE DELIVERY AND CUSTOMERS' SATISFACTION IN THE EEDC ABAKALIKI: TOWARDS THE ATTAINMENT OF SDG7 IN THE NIGERIAN POWER SECTOR
}

\author{
Ngozi Ewuim \\ Nnamdi Azikiwe University, Awka \\ Florence Agbodike \\ Nnamdi Azikiwe University, Awka \\ Ikechukwu Ogeze Ukeje \\ Nnamdi Azikiwe University, Awka \\ Udu Ogbulu \\ Nnamdi Azikiwe University, Awka \\ Johnpaul Chukwujindu Onele \\ Ebonyi State University, Abakaliki \\ $\&$ \\ Regina Suzana Ojogbane \\ Nnamdi Azikiwe University, Awka
}

\begin{abstract}
This paper focuses on Quality service delivery and customers' satisfaction within the framework of the Enugu Electricity Distribution Company (EEDC) in Abakaliki, Ebonyi State, Nigeria. The motivation behind this research is the persistence of power failure despite the privatization and unbundling policy of Federal Government after it failed to induce efficiency and effectiveness in the defunct Power Holding Company of Nigeria (PHCN). It adopts faceto-face interviews and documentary analyses. The study revealed that factors such as fear of contract review/withdrawal and lack of job security after the probation period (2014-2018) due to change of government are also other challenges that affect the performance of electricity supply by EEDC in Abakaliki. Also, monopoly and customers' self-pacifist behaviour were found to account for the persistence of the identified challenges identified. Findings further revealed that beating, harassment of EEDC staff and vandalization of power infrastructures by customers due to service failure or as an expression of frustration results in constant high bill estimation since staff cannot freely move to pick accurate meter readings in some premises where they had been confronted regularly. These result in a constant light interruption, overvoltage, load shedding, bulk billing, disconnections, and delay in the new connection. Paper concludes therefore that for the attainment of the current Sustainable Development Goals (SDGs) goal 7, which aims to ensure access to affordable, reliable, sustainable, and modern energy for all by 2030; Public Enterprises (PEs) should invest more in recruiting more qualified staff and improving their condition of service; while government institutionalize the contract concession to remove it from political influence, at least partially and finally, make clear its policy responsibility to assign clear areas of intervention between it and the company and invest robustly in infrastructure.
\end{abstract}


Keywords: Quality service delivery, customer's satisfaction, privatisation, power sector, challenges, Nigeria

\section{Introduction}

The current Sustainable Development Goals (SDGs) of the United Nations with 17 goals and 169 targets cannot be achieved without careful consideration of the role of energy (Edomah, Foulds \& Jones, 2017). Nigeria as the largest economy and most populous state in the entire continent of Africa (Offu, Ukeje \& Offu, 2018), is greatly challenged with the problem of reliable power supply (Ighodalo, 2018). The provision of adequate, affordable, accessible and sustainable electricity supply is critical to the attainment of sustainable development (Akinbami and Momodu, 2012). However, public service delivery in Nigeria has witnessed declining performance levels since colonial administrative period (Ukeje, Ogbulu, Onyema, Obi, \& Obasi, 2019). Kauzya (2015) posits that effective delivery of public services which includes energy is generally taken as a key function of government and a critical element in the implementation of 2030 Agenda for sustainable development and achieving the SDGs; mediated by sound governance indices and public administration through a strong partnership building (Farazmand, 2009) in the delivery process. Service delivery is the centre of all activities of public-private sector organizations because the government is constituted to serve the people and ensure the public good. Sound administrative-governance in public service delivery is measured by the quality and quantity of those citizen-centric and people-driven services rendered since the SDGs need an effective public service for successful implementation (Ukeje, Ndukwe, Chukwuemeka, Ogbulu \& Onele, 2019).

Lending their voices, Offu, Ukeje and Offu, (2018) argued that a viable, democratic, and responsive public service delivery is critical to the development of efficient private-sectordriven economy needed for Nigeria-African development; through a sound governance policy measures and or reforms in both political and administrative settings (Farazmand, 2012; 2017) that centres on citizens engagement. Sound governance requires adaptability, capacity building and development, innovations in policy and management and a sound administrative system that is dynamic, flexible, diverse in character, and solid in structure and value orientations (Farazmand, 2004).

The nature and practice of privatization policy, either by contracting out, outsourcing, or complete privatization through various schemes, "grounded on the idea of the supremacy of the market as an all-encompassing institution for a functioning society as well as the most viable and functioning institution in the economy" (Farazmand, 2002), can determine citizens' satisfaction-dissatisfaction measurement as well as the type of market structure created (either monopolistic or competitive structure). Privatization is primarily done to introduce effectiveness and efficiency, reduce government interference and administrative burdens, generate new investment, develop the capital market and deepen the financial system, provide the opportunity to introduce competition and enlarge individual choice and freedom (Ezeani, 2006; Ewuim, 2013). Privatization must result in better service at lower prices as desired by consumers who oftentimes, are not much bothered about economic philosophies (Adeyemo \& Salami, 2008).

Thus, in the context of this discourse, privatization means a deliberate attempt by the government to induce competitiveness and efficiency in public institutions through the new public management (NPM) and the new public governance (NPG) paradigm. However, this paper argues that government of Nigeria has only succeeded in creating another layer of 
powerful unaccountable monopolies through its privatization policies by neglecting the "competitiveness and citizens-choice" components in the stated policy objectives; often as the government is unable to deal with the politico-economic intervening components of the reform process. It remains arguable whether there can be competition in a monopolistic situation. For example, the poor service situation in the communication industry and the manner they deal with cases of reported service failure demonstrates clearly the audacity of secure business interest ostensibly due to 'market conquest'. It is not clear whether there are other government privatization policies which represent a fair competitive market situation in keeping with the true spirit of privatization. The implication of these is the circumvention of consumer choice and monopolistic exploitation. Offu, Ukeje \& Offu, (2018) posit that service delivery outcomes, therefore, determine the input-output variance of an organization and should be sufficiently enabled (input variance) to ensure competence, legitimacy, equity, efficiency, corporate good, and responsibility (output variance).

As former President Olusegun Obasanjo (2003) observed, "Nigerians have for too long been feeling short-changed by the quality of public service delivery as been characterized by the combined evils of inefficiency and corruption". However, cooperative action between government and citizens by institutionalising the whistle-blowing framework in public sector governance is capable of improving service quality in Nigeria's public service (Ukeje et al., 2019). Thus, on these stated problematic underpinned, former president, Chief Olusegun Obasanjo in the year 2003, constituted a committee of experts headed by Wendy Thomas to help Nigeria do a diagnostic audit of the system, examine the institutional environment for service delivery, reflect on people's lives and experiences and draw a road map for a service delivery programme. The service delivery programme should:

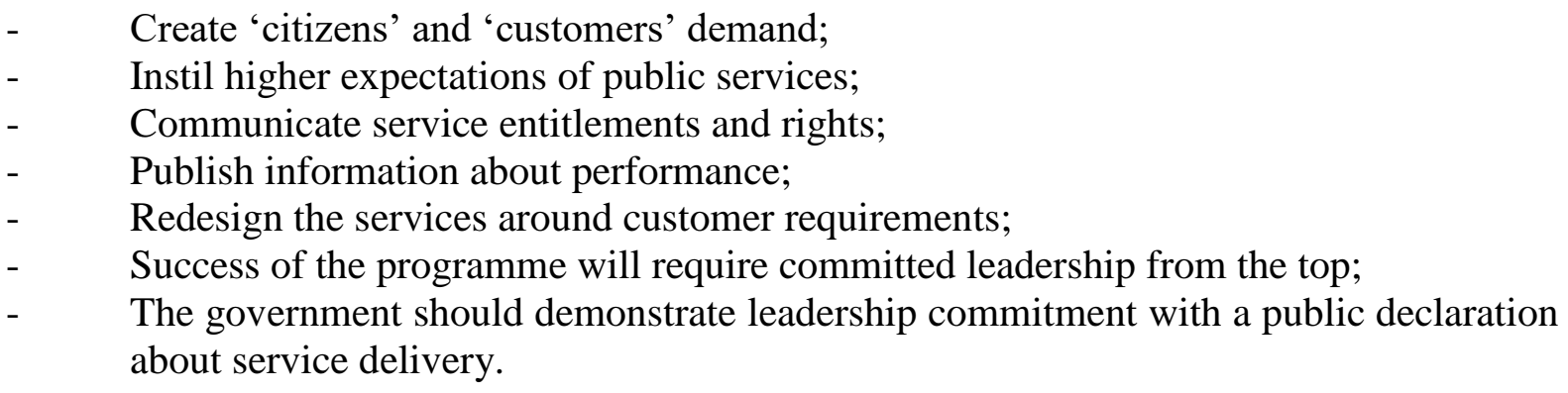

The extent these noble goals have been achieved is an only matter of debate between practitioners who see 'great leaps in public service reforms since 1999 and scholars who see little progress and largely business as usual efforts lacking the needed impetus to perform. According to the Servicom Reports (2003), effective service delivery entails the process of providing the basic services to which citizens are entitled in a timely, fairly, honestly, effectively and transparently. Effective performance of public services is underpinned by certain core values, which include, integrity, meritocracy, discipline, professionalism, patriotism and impartiality (Idike, Ukeje, Iwuala, Onele, Ekwunife, Nwachukwu \& Ogbulu, 2019). It is perhaps guided by the above that EEDC has the philosophy integrity, customer service and performance. However, it appears that governments view and commitment to the above stated is limited in scope. The evidence available suggests that such service efficiency mechanism like SERVICOM has not been extended to all areas of public interest like the privatized institutions. 
Consequently, in the present service situation of Nigeria as it affects her public sector in general and power sector in particular, Ezeani (2006) noted that the damaging effects of poor service delivery are on the amount of trust the public has in the ability of the government to provide quality and timely service delivery. In the words of Okechukwu and Ukeje (2016), the challenge of sustainable development has remained unresolved due to the lack of political will and good policies that promote sustainable development in the energy sector. Haque (1996) posits that the prevailing worldwide movement of privatization has created significant challenges to the public service particularly, to its legitimacy, ethics, and motivational foundation. However, it appears that governments view and commitment to the above stated is limited in scope. The evidence available suggests that such service efficiency mechanism and or reforms like SERVICOM (citizens-centred service delivery) has not been extended to all areas of public interest like the privatized institutions. The privatization of the power sector in Nigeria has suffered setbacks due to lack of good maintenance culture which has resulted in several situations whereby the industry has remained unviable to investors (Oluseyi, Akinbulire and Awosope, 2007) and lack of regular training, the human factor (Ukeje, 2019) accounts for a great deal of the power sector's current debilitating condition (Awosope, 2003; Abubakar, 2011). This is aggravated by the unavailability of specialized engineers and technicians for certain tasks as well as unpreparedness of the industry to pay an equitable amount as hazard allowance and insurance policy attached to the workers. As one opinion suggested:

The privatization of the power sector, while transparently conducted, was fraught with several missteps and set to go wrong from the start of the process. Four years after, the privatization has proven to be problematic and may result in a sovereign debt burden for Nigeria and Nigerians. The time has come for the government to be strict on ensuring that the privatization of the power sector is not derailed (Omonfoma, Premuim Times, 2017).

This points to the fact that government has not faithfully implemented the competitiveness component of the privatization programme leading to the emergence of new monopolies evidenced by the pattern of ownership of the stakes in the electricity sub-sector where division and allocation are somewhat regionalized. Government at all times should be prepared to demonstrate the political will to enforce as well as implement policy reforms (Okpata \& Ukeje, 2017; Ukeje, 2019). Absence of alternatives or competition (substitutes) is responsible for customer incapacitation and non-responsiveness of EEDC to service atonement and service appeals. Poor employee motivation and inadequate staffing also are contributing factors. Availability of power is a sine-qua-non for the much-desired industrialization in Nigeria. The problem, however, remains how to improve the capacity and motivation of EEDC staff for enhanced and sustainable service delivery in the sector.

\section{Conceptual review}

The synergy between governance, public services and sustainable development goals

Sustainable development is the development that meets the needs of the present without compromising the ability of future generations to meet their own needs. Thus, the SDGs 7 is the masterstroke in so far as economic development is concerned. This is because of its potency to trigger ambitious developments in other sectors of the economy. Access to affordable and clean energy is a sine qua non to improvements in Health, manufacturing, bureaucratic, social and other service delivery systems. 
For example, in targets number 7.2 (see figure 1 below), increase substantially the share of renewable energy in the global energy mix will lead to the cleaner atmosphere, improve the environment, health and reduce hazards associated with petro-carbon-driven energy framework. So in the study area, while the renewable energy alternative is yet unexplored, the challenge remains how to ensure regular and adequate energy levels both for household and industrial activities. The fear, however, is that due to the present state of things, management hardly focuses on this all-important goal. It might be helpful for both government and EEDC to explore the SDGs targets of $7 \mathrm{a}$ and $7 \mathrm{~b}$ to widen resource dragnet for improved investments in the sector while leveraging the "Third Sector" structure to engender a resilient administrative mix. This may provide the needed incentive for performance optimization in the EEDC framework.

As yet, the third sector partnership option remains largely unexplored and its potential to improving service outcomes in the Nigeria energy sector is yet untapped. It is argued that involvement of the already existing Electricity Committee Framework as a statutory management layer will help mobilize resources for investment, secure power infrastructure and broad supervising oversights on EEDC staff operations.

\section{Methodology}

In the course of this research, data were collected from the sample population through face-toface interviews with some pre-selected EEDC staff and members of the Electricity Committee in Ohatekwe, Agalegu community. Data were then analysed using documentary analysis. Responses and documents were based only on the post-privatisation era. Hence, documents obtained from EEDC show an overall low revenue collection rate per meter on average. Thus, evidencing challenges to building robust institutional capacity for improved performances in the power sector. Interviewees agree that fear of contract termination, lack of institutional and pervasive corruption are challenging to EEDC operations.

Similarly, poor management and negligence of the Electricity committee (third sector) alternative in line with co-production philosophy were also identified. Specifically, interviewees were interviewed based on their experiences and degrees of involvement in the overall gamut of power sector management, responsibilities and expectation. The focus was to identify common trends and attempt to assign values to the identified parameters and to see whether the additional alternative (third sector) holds a prospect for improvements in human and material resources improvements. However, because the identified parameters are not exhaustive in dealing with the problems in the power sector, the third sector option has become indispensable. 
Figure: 1. Overview of sustainable development goal 7

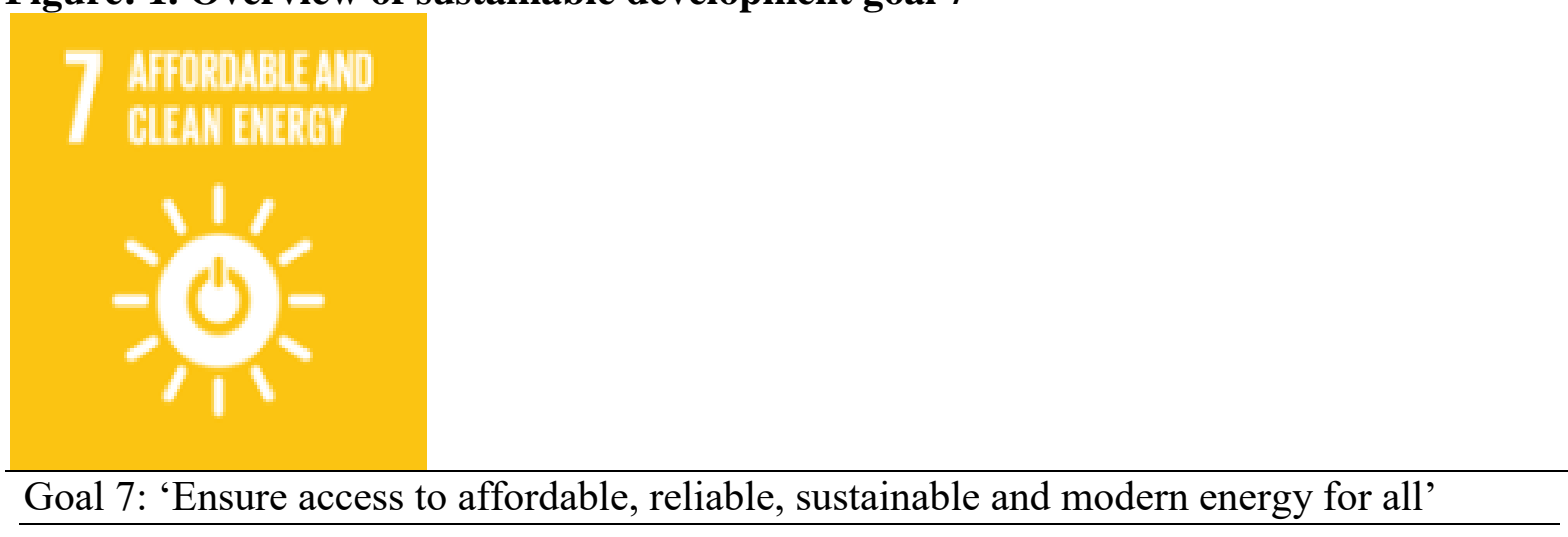

7.1 by 2030, ensure universal access to affordable, reliable and modern energy services

7.2 increase substantially the share of renewable energy in the global energy mix

\section{3 double the global rate of improvement in energy efficiency}

7.a by 2030 , enhance international cooperation to facilitate access to clean energy research and technology, including renewable energy, energy efficiency and advanced and cleaner fossil-fuel technology, and promote investment in energy infrastructure and clean energy technology

7.b by 2030, expand infrastructure and upgrade technology for supplying modern and sustainable energy services for all in developing countries, in particular least developed countries, small island developing States, and land-locked developing countries, under their respective programmes of support.

Source: UN General Assembly 2015, page 19

\section{Service delivery and the challenges of the power sector in Nigeria}

Poor commitments of workers and shareholders, corruption and exploitation arguably are fallouts of the above-stated problem. Challenge, however, remains how to ensure job/ contract security as well as proper conditions of service for the attainment of the much-desired optimum service delivery for economic transformation in Nigeria.

Interview with the staff of EEDC indicated that the Distribution Company, in its bid to maximize their earnings and minimize cost, make use of poor and inexperienced staff. According to the staff interviewed, this has led to poor meter reading and constant customer destructive rampage on EEDC's facilities and demonstrations at the company's offices. As a punitive measure to the irate customers, the Company's staff frequently embarks on mass disconnection of their clients and high monthly bill estimation. The aim would be to cover the much-needed cost whether or not service is rendered. For days, weeks, and sometimes months, the entire service area would be without electricity; yet the EEDC would send estimated bills to those areas.

Attainment of high performance and quality service delivery in the power sector is predicated on proper funding, institutional capacity and government support and ability to provide adequate transformers in the various service areas, zones or location. This agrees with the 
research findings of Nwankwo, Ewuim and Asoya (2012) that institutionalised capacity building is tangential in addressing the management cum leadership problem of public enterprises in Nigeria. In all spheres, Africa, Europe, Americas, Asia, and the Pacific, service provides the central gauge for public governance (Offu, Ukeje \& Offu, 2018). Umoru, and Omolara, (2013) in discussing the level of performance for improved service delivery in Nigeria, revealed that the level of productivity and socio-economic growth has been unsatisfactory since independence and especially in most Africans states and therefore calls for the institutionalization of the New public management and public service reform to increase the level of public service performance and quality service delivery to the public (Olufemi and Kehinde, 2010). Fagbemi (2006) alludes that the impact of governance on productivity delivery could be seen in the way public services are delivered which should ensure effective consultation platform with citizens, having service standards, equal access of citizens to services and full and accurate information. This means that the destiny of the state or nation and its public sector is tied and overthrown if service is not rendered effectively and efficiently. PEs should be politically neutral, impartial, loyal, transparent, accountable and of high integrity, with good leadership style if effective service delivery is to be achieved (Obiwuru; Okwu and Akpa, 2011).

Imhonopi and Urim (2013) assert that Nigeria's nationhood has been caught in the whirlpool of a corrupt public sector which has undermined the effectiveness of the whole system in the face of good governance. Public sector organisations in every civilized or democratic society are legitimate expectations used by governance in meeting the basic needs of all citizens (Skweyiya, 1997). Hence they are expected to promote and maintain a high standard of professional ethics in an accountable, transparent and development-oriented manner. Adegoroye (2006) asserts that despite several reforms instituted by different successive governments to improve the overall performance of PEs (public sector) in Nigeria in terms of productivity, efficiency and effectiveness, public service delivery is still being characterized with tradition-bound, operating within a centralized structure and inadequate staff development practices because of the nature of administrative and political leadership ideology. This is also replicated in Nigeria power sector. According to Nwankwo, Ewuim and Asoya (2012), the government should provide a coherent and efficient regulatory framework and supportive policy that is consistent with the nature and function of public enterprises for better performance. The regulatory framework should be simple, predictable and efficient; should minimize bureaucratic delay and obstructions to business operation, and should avoid conflict and duplication with other laws. Another motivation problem experienced by workers in the sector is the issue of environmental safety.

According to Arowolo (2010), poor service delivery is a product of ethical depravity in government ministries and establishments, leading to low performance and low level of productivity. Public enterprises (PEs) platforms should be able to tackle the problem of poor service delivery that has hampered the development of Nigerian public sector, and bring about far-reaching transformation in the service, in a timely, fair, honest, effective and transparent manner (Oswald, 2014). A country's ability to invent new ideas and achieve high performance depends on the quality of its motivated workforce (Tompa, 2002). Improving staff performance, utilization and productivity is predicated on proper acquisition of skills, training and knowledge, proper remuneration, rewards, safe and conducive work environment and job/contract security in the workplace. However, Okechukwu, Ukeje and Ekwunife (2016) observed that customer's satisfaction of service delivery is an indispensable tool in determining the level of performance and public trust. This is because effective and efficient service 
delivery is an essential element of any governance particularly in this period when the nation is currently going through an economic recession which has greatly affected the power sector (Gaskia, 2017). This lends credence to Ewuim, Agbodike and Igbokwe-Ibeto (2015) position on the need for a workable intervention policy programme since organizations operate in a volatile and uncertain environment with increased demands on service delivery (Ndukwe, Elom, Ukeje, and Anigbata, 2016) and the need to meet and provide for the basic needs of citizens, as well as to manage the collective affairs of society in a manner that enhances the welfare of the citizens and promote sustainable and progressive development in the state (Osawe, 2015). Moreover, from the respondent's view, it was also gathered that the provision of transformers for customers' use experiences serious delays, particularly where there is/ are no big shot(s) to influence this provision.

This study has shown that traces of inefficiency, poor service delivery, injustices, ethical violations and low performance in EEDC pose a serious challenge to the tenets of privatisation in Nigerian governance and underscores the need to re-engineer a service rebirth. The poor service challenges are characterised by difficult sometimes confusing payment procedures not clearly displayed; customers do not see EEDC as an efficient organisation; EEDC staff don't explain delays; hidden charges (bills) for services rendered; inadequate records and management of complaints resulting in customers' dissatisfaction and conflict. Thus, removing the challenges of poor power supply and inefficiencies in the sector will enhance the realisation of the objectives of the current Sustainable Development Goal 7 by 2030 by providing access to affordable, reliable, sustainable, and modern energy for all.

This same epileptic power supply currently experienced in Nigeria prompted most countries in the world like the governments of India, China, Mexico and South America in general to hand over the entire management of electricity generation to the hands of private investors in which has led to a wonderful performance in the industry (Awosope, 2014) but in Nigeria, the impact of such reforms is yet to be felt almost six years after the programme.

\section{Findings}

The study revealed the following findings:

1) EEDC lacks the institutional capacity and capability to deliver quality and satisfactory services to the public (customers); inabilities to provide adequate transformers in the various service areas/ zones thus jeopardizing the goal of achieving quality, reliable and sustainable power supply in this era of Sustainable Development Goals (SDGs) in Abakaliki.

2) Fear of contract review/withdrawal and lack of job security after the probation period (2014-2018) due to change of government is also another challenge of improved electricity supply by EEDC being a private company. Moreso, as a private company, the employees are faced with job insecurity since the process of firing the members of staff is highly arbitrary, not giving room for due process.

3) The insecurity of EEDC staff and their installations: beating, harassment of EEDC staff and vandalization of power infrastructures by customers due to service failure or as an expression of frustration resulting in constant high bill estimation since staff cannot freely move to pick accurate meter readings in some premises where they had been confronted regularly. 


\section{Conclusion}

Given the research findings and taking into consideration the overall performance of EEDC from the standpoint of customers (citizens) satisfaction, it is quite reasonable to conclude that EEDC does not have the institutional capacity and support to satisfy the users of electricity products in the study area. This poses a serious challenge to the prospects of attaining the current Sustainable Development Goal 7 by 2030 in the power sector in the study area. The findings disagree with the earlier statement of the outgoing Chief Executive Officer of the EEDC, Engr. Suleiman Yahaya, who said that the Enugu distribution company was made up of 18 business units covering Imo, Anambra, Enugu, Abia and Ebonyi States and have a resourceful workforce that, if given the right infrastructure, would grow into a sustainable and profitable company. The company is presently challenged with many critical factors such as understaffing, poor leadership influence/ style, lack of time management, lack of qualified engineers as opposed to the findings of Awosope (2014), job insecurity as a result of public beatings and harassment of EEDC staff by customers as well as fear of the possibility of contract termination at the expiry of probation period.

The findings also revealed that the electricity consumers in Abakaliki, the capital of Ebonyi State have bemoaned the poor service delivery in their area as it ranges from the constant power interruptions, low voltage, unreliable load shedding, illegal meter adjustments, estimated billing, vindictive/punitive disconnections, delay in the new connection, lack of effective complaints management feedback mechanism in the sector even with the presence of the NERC. Thus, more than 50 per cent of the consumers in the study area have alternative power supply source, at least (I-pass-my-neighbour) thereby driving the state into a generator-based economy. Corroborating this, our data show that the customers have no trust, confidence and reliance on their power provider-EEDC.

\section{Recommendation}

In the light of the above, this study is recommending a service efficiency approach where the functionality of the Nigerian Electricity Regulatory Commission (NERC) as a regulatory body will be tested using the EEDC customers index. In this case, the service efficiency of EEDC will serve as a litmus paper to test the service efficiency of NERC. EEDC, on the other hand, must increase her workforce to help bring about ease in running the affairs of the company, particularly as it affects attending to her numerous customers. Besides, the practice of recruiting inexperienced staff to pay them less and increase the company's profit must be checked since this inexperience influences the service rendered. On the consequence of this public distrust and dissatisfaction on the services of the EEDC, the study recommends the need for the Federal Government, through the National Council of Privatisation (NCP) and the Bureau of Public Enterprises (BPE) to reform and liberalise the nation's power sector sustainably and reliably. Job insecurity, which seems to be a popular feature of the private sector should be addressed in such a way that due process, will be brought to bear to ensure job protection, quality service delivery and sustainable development in the sector.

\section{References}

Abubakar, M. K. (2011). Welcome Address at the Summit on Energy and Sustainable Economic Growth, Energy Commission of Nigeria Organized workshop at LadiKwali Hall, Sheraton Hotel and Towers, Abuja, 9th - 10th March 2011. 
Adeyemo, D. O. \& Salami, A. (2008). A review of privatization and public enterprises reform in Nigeria. Contemporary management research, 4(4): 401-418.

Adegoroye, G. (2006) Public Service Reform for Sustainable Development: The Nigerian Experience. Being a Keynote Address Presented at the Commonwealth Advanced Seminar, Wellington New Zealand.

Akinbami, J-F. K. \& Momodu, A. S. (2012). Electrical energy production pathway for sustainable development in Nigeria: a case study of energy recovery from agro-forestry wastes. International journal of sustainable energy, 31 (3): 155-173.

Arowolo, D. (2010). "The State, Bureaucracy and Corruption in Nigeria". Academic Leadership Online Journal: College of Education \& Technology Fort Hays State University, Vol. 8 (3).

Atume, E., Igberi, C. O., Udude, C. C. \& Odo, S. I. (2016). Power Supply, Average Manufacturing Capacity Utilization and Unemployment in Nigeria. Asian Research Journal of Arts \& Social Sciences. 1(2): 1-15

Awosope, C. A. (2014). Nigeria electricity Industry: issues, challenges and solutions. 38th public lecture series. Vol. 3, no. 2, pp.1-40.

Awosope, C. O. A. (2003). Power Demanded but not supplied: The agonizing roles of emergency power supply and transmission system inadequacy, University of Lagos Inaugural Lecture Series, 10th September.

Balaam, D. \& Veseth, M. (2005) Introduction to international political Economy (Third Edition). New Jersey: Pearson Education Inc.

Buchanan, James M. (1967). Public Finance in Democratic Process: Fiscal Institutions and Individual Choice, UNC Press.

Edeh, J. N; Ogbonna, S. \& Ukeje, I. O. (2011). The Impact of Employee Motivation and Psychological Contract in Tertiary Institutions: An Appraisal of the Federal, State and Private Universities in Nigeria. Nigerian Public Administration Review, 3 (3) 59-74.

Edomah, N., Foulds, C. \& Jones, A. (2017). Policymaking and energy infrastructure change: a Nigerian case study of energy governance in the electricity sector. Energy Policy, 102, 476-485.

Etu, I. A, Ahmed, E.A. \& Jack, K. E. (2015). Assessment of Nigeria's Power Situation and the Way Forward. International Journal of Latest Research in Engineering and Technology (IJLRET). Vol. 1 (4) PP 24-31

Ewuim, N. C, Agbodike, C. F. \& Igbokwe-Ibeto, C. J. (2015). Gender inequality, poverty alleviation and Sustainable development in Nigeria: lessons from the RAPTI women empowerment project, NEPAL. International Journal of Accounting Research. Vol. 2 ( 7): $37-50$ 
Ezeani, E. O. (2006). Fundamentals of public administration. Snaap Press Ltd. Enugu, Nigeria.

Fagbemi, A. O. (2006). Customer Service Delivery in Public Sector Management. Lagos Concept Publications Ltd.

Farazmand, A. (2002). Privatization and globalization: a critical analysis with implications for public management education and training. International review of administrative sciences, 68(3): 355-371.

Farazmand, A. (2004). Sound Governance. Policy and administrative innovations. Westport, CT: Praeger.

Farazmand, A. (2009). Building administrative capacity for the age of rapid globalization: a modest prescription for the twenty-first century. Public administration review, 69(6): $1007-1018$

Farazmand, A. (2012). Sound governance: engaging citizens through collaborative organizations. Public organization review. 12: 223-241

Farazmand, A. (2017). Governance reforms: The good, the bad, and the ugly; and the sound: Examining the past and exploring the future of public organizations. Public Organization Review, 17, 595-617.

Festinger, L. (1957). A Theory of Cognitive Dissonance. California: Stanford University Press. https://en.wikipedia.org/wiki/Cognitive_dissonance

Festinger, L. (1962). "Cognitive dissonance". Scientific American.207 (4): 93-107. doi: 10.1038/scientificamerican1062-93.

Haque, M. S. (1996). Public service under challenge in the age of privatization. Governance, an international journal of policy and administration, 9(2): 186-216.

Idike, A., Ukeje, I. O., Iwuala, H. O., Onele, J. C. Ekwunife, R. A., Nwachukwu, K., and Ogbulu, U. (2019). The Practice of Inclusive Representation in Nigeria Bureaucracy: The Federal Character Principle experience. Cogent Social Sciences, https://www.tandfonline.com/doi/abs/10.1080/23311886.2019.1601545

Iloh, G; Ofoedu, J. N; Njoku, P.U; Odu, F.U; Ifedigbo, C.V \& Iwuamanam, K.D. (2012). Evaluation of patients' satisfaction with quality of care provided at the National Health Insurance Scheme clinic of a tertiary hospital in South-Eastern Nigeria. Nigerian Journal of Clinical Practice; 15: p469-474.

Imhonopi, D. \& Urim, U.M. (2013). Leadership Crisis and Corruption in the Nigerian Public Sector: An Albatross of National Development. The African Symposium: An Online Journal of The African Educational Research Network. Vol. 13, No. 1. Pp 78-87

Ighodalo, A. (2018). Public administration and sustainable national development in Nigeria's fourth republic. Advances in Social Sciences Research Journal, 5(3) 466-478. 
Jones, G. R. \& George, J. M. (2008). Contemporary Management. Accessed 8/15/2017. https://en.wikipedia.org/wiki/Employee_motivation

Kauzya, J. M. (2015). From implementation of MDGs to 2030 sustainable development agenda: what will it take from government and public administration to achieve sustainable development goals (SDGs). Paper presented during the $20^{\text {th }}$ CLAD Congress Lima Peru, November 2015.

Lester, S.W. \& Kickul, J. (2001) "Psychological contracts in the 21st century: What employees value most and how well organizations are responding to these expectations", Human Resource Planning, Vol. 24 (1), 10-21.

Mcdermott, A.O, Conway, E., Rousseau, D.M., \& Flood, P.C (2013) Promoting effective Psychological contracts Through leadership: the Missing link between HR Strategy and performance. Human resource management. vol. 52, (2). Pp. 289-310

Mueller, D. (2003). Public Choice III. Cambridge: Cambridge University Press.

Munck, G. (2002). "Rational Choice Theory in Comparative Politics", in H. Wiarda (ed.) New Directions in Comparative Politics. Boulder: Westview.

Ndukwe, C; Elom, C; Ukeje, I. O. \& Anigbata, D.O. (2016). Re-positioning Human Resource Practitioners for Effective Change Management in Times of Severe Austerity: A Policy Framework for Service Delivery in Nigeria Public Sector. Journal of Resources Development and Management.Vol.22:40-49. http://iiste.org/Journals/index.php/JRDM/article/view/31748

Nwalado, E. N., Obro, S. \& Ofuasia, J. N. (2012). The problems of power generation in Nigeria: implication for Economic development. Multidisciplinary journal of empirical research volume 10 no. 1. Pp.1-9

Nwankwo, F., Ewuim, N., \& Asoya, N. P. (2012). Role of Cooperatives in Small and Medium Scale Enterprises (SMEs) Development in Nigeria: Challenges and the Way Forward. An International Multidisciplinary Journal, 6 (4): 140-156

Obiwuru, T C; Okwu, T. \& Akpa, V. O. (2011). Effects of Leadership Style on Organizational Performance: A survey of selected small scale Enterprises in Ikosi-Ketu Council development Area of Lagos State. Australian Journal of Business and Management research vol.1 no.7 100-111. Nigeria.

Ogbe, A. A., Ajanya, M. A. \& Anaele, C. (2013). Relationship between Employees' Motivation and the Performance of Power Holdings Company of Nigeria in the 21st Century. International Journal of Finance and Management in Practice, 1 (1 \& 2):30-40.

Ochugudu, A.I. \& Onodugo, V. A. (2013). Power sector reform deliverables: how well and how good to Customers? International journal of management technology, 1(1): 1- 14. 
Okechukwu, G. P. \& Ukeje, I. O. (2016). Gas Flaring and the Contours in the Mismanagement of Nigeria Niger-Delta Environment. Mediterranean Journal of Social Sciences. 7 (5) 263271. http://www.mcser.org/journal/index.php/mjss/article/view/9461

Okechukwu, G. P.; Ukeje, I. O. \& Ekwunife, R. A. (2016). The Melting Point between SERVICOM and Service Failure: A Labyrinth for Efficient Service Delivery in Nigeria. IOSR Journal of Humanities and Social Science (IOSR-JHSS), 21(5): 01-10. http://www.iosrjournals.org/iosr-jhss/pages/21(5)Version-2.html

Okechukwu, G.P.; Ndukwe, C. \& Ukeje, I. O. (2015). Motivation and Sustainable Leadership in Nigeria: The Implications for Service Delivery in the Health Sector.Public Policy and $\begin{array}{llll}\text { Administration } & \text { Research } & \text { 29-37. }\end{array}$ http://www.iiste.org/Journals/index.php/PPAR/article/view/26694

Oluseyi, P. O. Akinbulire, T. O. \& Awosope, C. O. A. (2007). Solving the technical problems facing electrical energy development in Nigeria, UNILAG fair and conference in Awosope, C. A. (2014) Nigeria Electricity Industry: issues, challenges and solutions. 38th public lecture series. Vol. 3, no. 2, pp.1-40.

Olufemi, F. J \& Kehinde, A. D (2010). Public Sector Reform in Africa: Issues, Lessons And Future Directions. Journal of Sustainable Development in Africa. Volume 12, No.8.pp 145-157

Okpata, F.O. \& Ukeje, I. O. (2011). Bureaucratic Communication in Organizational Management: The Challenge of New Employees in Public Service Organization. Nigerian Journal of Business (NJB), 5 (1): 234-240

Okpata, F. O. \& Ukeje, I. O. (2017). Justice and human dignity in the development of Nigerian federalism and public service system: the problem of good governance. International Multidisciplinary Academic Research Journal, 1(1), 44-69

Omonfoma, O. (2017, June 5). Solutions to addressing the challenges of the power sector privatization. Premium Times. Available at: https://opinion.premiumtimesng.com/2017/06/05/solutions-to-addressing-the-challengesof-the-power-sector-privatisation-by-odion-omonfoman/

Ongalo, E. A. \& Tari, J. (2015). Effect of Employee Motivation Strategies on Organizational Performance: A Case of Electricity Generating and Distribution Firms in Kenya. European Journal of Business and Management, 7(8) 55-65

Osawe, C. O. (2015). Nigerian public service performance in a dysfunctional ecology: issues, challenges and the way forward. Review of public administration and management, $3(7): 45-57$.

Oswald, A. (2014) "Service Compact: A Moral Imperative for Effective Service Delivery. Being a paper delivered in a workshop on SERVICOM organised by the Cross River State Government, Nigeria. Available: http://www.crossriverstate.gov.ng/index.php?option=com_content\&view=article\&id=3 67:servicom-boss-charges-auditors-to-imbibe-right-attitude-to$\underline{\text { work } \& \text { catid }=149: \text { servicom } \& \text { Itemid }=682}$ 
Seniwoliba, A. J. \& Nchorbuno, A. D. (2013). Examining the role of motivation on employee performance in the public sector in Ghana. Merit Research Journal of Education and Review. 1(10) 227-249.

Skweyiya, Z. (1997). White Paper on Transforming Public Service Delivery. Department of Public Service and Administration, (WPTPS) in South Africa.

Offu, P. O., Ukeje, I. O. \& Offu, O. F. (2018). Service: The Matrix of Good Governance in Nigeria-Africa. In: Farazmand A. (eds) Global Encyclopedia of Public Administration, Public Policy, and Governance. Springer, Cham. Doi: https://doi.org/10.1007/978-3-319$\underline{31816-5 \_3499-1}$

Ukeje, I. O., Ogbulu, U., Onyema, U. E., Obi, V., \& Obasi, V. U. (2019). Bureaucratization and Service Delivery in Nigeria. In: Ali Farazmand (Ed.), Global Encyclopedia of Public Administration, Public Policy, and Governance, Springer. http://springer.iqtechnikum.de/referenceworkentry/10.1007/978-3-319-31816-5_3824-1

Ukeje, I. O. (2017). Employee Motivation and the Performance of Power Sector: A study of Enugu Electricity Distribution Company (EEDC) in Abakaliki, Ebonyi State, Nigeria. Unpublished PhD seminar submitted to the Department of Public Administration, Nnamdi Azikiwe University, Awka.

Ukeje, I. O., Ndukwe, C., Chukwuemeka, E., Ogbulu, U., \& Onele, J. P. (2019). Public service recruitment practices and implications for sustainable development in Ebonyi State, Nigeria. International journal of public administration, https://doi.org/10.1080/01900692.2019.1636394

Ukeje, I. O. (2019). Human capital development and implementation of food security and poverty reduction policy: diagnosing obstacles and prescribing options for sustainable development goals in Nigeria. A Paper presented at the $1^{\text {st }}$ FMSS International Conference, Alex Ekwueme Federal University, Ndufu-Alike, Ebonyi State, Nigeria, $25^{\text {th }}$ $27^{\text {th }}$ June.

Ukeje, I. O. (2019). Implementation of food security and poverty reduction policy in Nigeria: a case study of Ebonyi state agro-empowerment programme. Unpublished $\mathrm{PhD}$ seminar, Department of Public Administration, Nnamdi Azikiwe University, Awka.

Umoru, D. \& Omolara, J. Y. (2013). Labour Productivity and Health Capital in Nigeria: The Empirical Evidence. International Journal of Humanities and Social Science. Vol. 3 No. 4

United Nations General Assembly (2015). Resolution adopted by the general assembly on 25 September 2015, ref. A/RES/70/1. Annual Report, New York 